\title{
Гігантська міксома заочеревинного простору малої миски та лівої сідниці: опис клінічного випадку
}

\author{
I. D. HERYCH, A. S. BARVINSKA, D. L. ROMANCHAK, R. V. YAREMKEVYCH \\ Lviv National Medical University by Danylo Halytsky \\ Lviv Communal City Clinical Emergency Care Hospital
}

\section{GIANT MYXOMA OF RETROPERITONEAL SPACE OF PELVIS AND LEFT BUTTOCK: CASE REPORT}

\begin{abstract}
Проаналізовано літературні дані про пухлиноподібні утвори великих розмірів заочеревинного простору, малої миски і сідниць та екстракардіальні міксоми. Наведено рідкісний клінічний випадок гігантської міксоми заочеревинного простору малої миски і лівої сідниці. Особливості полягали у тривалості захворювання (44 роки), об'смі кісти (1865 мл), поширениі процесу, застосуванні всіх доступни діагностичних методів та нетиповій лікувальній тактиці - хірургічне втручання в два етапи з формуванням декомпресійної нориці.

Literature review about extracardiac myxoma and giant tumor of retroperitoneal space, pelvis and buttocks was analyzed. A case report of giant myxoma of retroperitoneal space of pelvis and left buttock is presented. Features of this case is the disease duration (44 years), volume of tumor (1865 ml), spreading of process, using all available diagnostic methods and atypical therapeutic tactic - surgery in two stages with the formation of decompressive fistulas.
\end{abstract}

Міксома - доброякісна пухлина, що походить зі сполучної тканини ембріональної будови, містить базофільні клітини, які продукують муцин, повільно росте, рентгенологічно майже не відрізняється від кісти [1]

Екстракардіальні міксоми вперше описані Стоутом у 1948 р. [2]. Міксоми м'яких тканин $\epsilon$ рідкісною патологією, інцидентність їх виявлення становить від 0,10 до 0,13 випадків на 100000 населення [3]. Описані варіанти локалізації таких утворів у м'язах спини [4-7], нижньої кінцівки [8], підшкірній клітковині [9], легенях [10], головному мозку [11], нирках [12]. Загалом клінічний перебіг таких пухлин $\epsilon$ безсимптомним, причиною звернення до лікарів можуть бути наявність утвору, косметичний дефект або больовий синдром [7]. Діагностична програма передбачає пункційну або ексцизійну біопсію [13], інструментальні методи обстеження (ультразвукова діагностика, комп'ютерна томографія, магнітно-резонансна томографія) часто утвір є знахідкою під час перечислених обстежень $[1,14,15,16]$. Лікування міксом полягає у хірургічному видаленні пухлини $[2,17]$.

Метою роботи було 3'ясування обставин клінічного перебігу та особливостей лікувальної тактики гігантської міксоми заочеревинного про- стору малої миски та лівої сідниці на підставі аналізу клінічного випадку.

Опис клінічного випадку. Хворий П. віком 74 роки госпіталізований 25 січня 2012 р. у хірургічний відділ зі скаргами на наявність пухлиноподібного утвору лівої сідниці, який практично унеможливлює виконання фізіологічних потреб (дефекацію), періодичне відчуття печії шкіри в ділянці даного утвору. Хворіс впродовж 44 років - у 1968 p. вперше відмітив невелику пухлину лівої сідниці. За наведений період пухлина поступово збільшилася у розмірах, періодично на її нижньому полюсі утворювалися нориці, через які впродовж декількох днів виділялася густа прозора рідина жовтуватого кольору. За період останніх 5-6 років виділень не було, нориці не виникали, однак утвір особливо інтенсивно збільшився в розмірах

Об' єктивно. Загальний стан відносно задовільний. Шкіра і видимі слизові блідо-рожеві, чисті. Температура тіла у межах норми. Дихання везикулярне, ЧД - 18 д. p./хв. Тони серця приглушені, ритмічні. Пульс - 72 уд./хв, задовільних характеристик. АТ - 180/100 мм рт. ст. Зі сторони інших органів та систем патологічних змін не виявлено.

Status localis. Ліва сідниця збільшена в розмірах за рахунок пухлиноподібного утвору розміром 
$20 \times 30 \mathrm{~cm}$, без ознак запалення, щільної еластичної консистенції, безболісного, з ділянками флуктуації, по нижньому полюсу визначаються невеликі (до 12 см) рубцеві зміни шкіри.

Встановлено попередній діагноз: "Кіста лівої сідниці". Окреслено план обстеження: загальні та біохімічні аналізи, електрокардіографія, ехокардіографія, консультація терапевта, рентгенографія органів грудної клітки і черевної порожнини, ультрасонографія органів черевної порожнини й ураженої ділянки, фібросигмоскопія, цистоскопія, консультація уролога, комп'ютерна томографія живота і малої миски.

Результати обстежень такі. Загальні і біохімічні аналізи в межах норми. Зі сторони серцево-судинної системи - гіпертонічна хвороба, ішемічна хвороба серця, постінфарктний кардіосклероз. Зі сторони інших органів та систем - без патологічних змін. Ультрасонографічно стверджено у порожнині малої миски наявність утвору рідинної щільності, який відхиляє пряму кишку, простату і сечовий міхур вперед і вгору, розміром $12 \times 11 \mathrm{~cm}$, що розповсюджується на крижову ділянку та ліву сідницю; при огляді зі сторони сідниці візуалізовано у товщі лівої сідниці зону розрідження $15 \times 12$ см із неоднорідним рідинним вмістом. Ендоскопічно виявлено екзодеформацію прямої кишки, сечовий міхур без особливостей. Висновок комп'ютерної томографії: заочеревинно позаду прямої кишки справа масивний кістозний утвір однорідної рідинної щільності (гелеподібної консистенціі), багатокамерний, поширюється вгору по заочеревинному простору та, розшаровуючи м'які тканини, латеральніше від куприка і назовні, - гігантська кіста заочеревинного простору, малої миски і сідниці. За даними комп'ютерної томографії обчислено об'єм утвору - $1865 \mathrm{~cm}^{3}$.

31 січня 2012 р. під місцевою анестезією проведено пункційне дренування порожнини кісти за Бредлі: отримано 60 мл в'язкого гелеподібного прозорого вмісту без запаху різнорідного кольору (від світло-жовтого до бурого), у порожнину введено трипортовий катетер Бредлі, виділилося ще 40 мл аналогічного вмісту, після чого об' $є$ м сідниці візуально зменшився. Післяопераційний період без ускладнень, дренаж функціонував задовільно.

Мікроскопія вмісту кісти: 10-12 еритроцитів та $0-1$ лейкоцит у полі зору. Біохімічний аналіз вмісту кісти не вдалося провести з огляду на його гелеподібну консистенцію.

8 лютого 2012 р. під перидуральною анестезією проведено резекцію кісти, ексцизійну біопсію та марсупіалізацію кісти. У післяопераційному періоді сформовано норицю для декомпресії кісти. Перебіг без ускладнень.
Гістологічний висновок: стінка порожнистого утвору складається зі сполучної тканини 3 надмірною кількістю судин різного типу і діаметра, стінки потовщені, склерозовані, навколишня сполучна тканина фібротизована, множинні вогнища міксоматозу - ангіоміксома змішаної будови.

Контрольний огляд через 2 роки: скарг не висловлює, загальний стан задовільний, кіста не збільшується за рахунок постійного дренування гелеподібного вмісту через норицю, що уможливлює фізіологічні потреби пацієнта.

Обговорення. Гігантські утвори сідниці, малої миски та заочеревинного простору трактуються в літературі як рідкісна патологія: міксома сідниці [14, 18-22], епідермальна кіста сідниці [15, 23, 24], епідермальна кіста періанальної ділянки $[25,26]$, ліпома [27]. Розміри таких утворів перебувають у межах від 8 до 28 см у діаметрі $[14,15,18,23]$; як одна 3 найбільших пухлин наведеної локалізації описана ліпома розміром 55 см у діаметрі, масою 9 кг [27]. Найбільшу кількість клінічних спостережень внутрішньом'язової міксоми (51 паціснт) досліджено Nielsen G. P. і співавт. [17].

Наведений клінічний випадок заслуговує на увагу за цілою низкою особливостей: як анатомічних, так і діагностичних та лікувально-тактичних.

Серед описаних у літературі утворів (міксом, кіст, ліпом тощо), які розповсюджуються заочеревинним простором через малу миску до сідниць, випадок пацієнта П. вирізняється як розмірами (понад 22,7 см за довжиною), так і тривалістю захворювання (44 роки). Слід відмітити, що пацієнт (чоловік віком 74 роки) не належить до популяції, у якій часто діагностуються міксоми, - це особи віком 40-60 років, у більшості жінки (70\%) [3].

Діагностичний процес передбачав застосування усіх доступних додаткових методів обстеження, відповідав галузевим стандартам і світовій практиці $[2,16,22]$ і забезпечив оцінку анатомічної локалізації утвору. Перша діагностична маніпуляція (пункційне дренування порожнини кісти за Бредлі) мала за мету оцінити вміст кісти і можливості здійснити часткову ії декомпресію. Слід відмітити, що для міксом і кіст з гелеподібним вмістом не рекомендовано проводити пункційну голкову біопсію $[22,28]$. Остаточно діагноз встановлено після ексцизійної біопсії та патогістологічного дослідження.

Суттєво відрізнявся описаний клінічний випадок від наведених у літературі за лікувальною тактикою. Відповідно до наукових публікацій стандартом лікування міксом $\epsilon$ хірургічне видалення пухлини $[3,21,22,29]$. Однак у даному випадку, з огляду на вік пацієнта і наявність супутньої патології, анатомічні особливості поширення процесу (заоче- 
ревинний простір малої миски, сідниця), неможливість остаточно верифікувати патогістологічну характеристику кісти на доопераційному періоді, було прийнято рішення про хірургічне лікування в два етапи. Перший - пункційне дренування, вислідом якого була часткова декомпресія кісти (власне, з'ясування, чи така процедура можлива). Другий - марсупіалізація кісти з ексцизійною біопсією, що дало остаточну відповідь про характер патології, патогістологічну структуру ураження і забезпечило формування постійної декомпресійної нориці, а відповідно, й створило умови для комфортного життя паціснта. Такий підхід дозволив уник-

\section{СПИСОК ЛІТЕРАТУРИ}

1. Schwartz H. S. Recognizable magnetic resonance imaging characteristics of intramuscular myxoma /H. S. Schwartz, R. Walker// Orthopedics. - 1997. - Vol. 20, № 5. - P. 431-435.

2. Stout A. P. Myxoma, the tumor of primitive mesenchyme / A. P. Stout // Ann. Surg. - 1948. - Vol. 127. - P. 706-719.

3. Intramuscular myxoma / O. Heymans, M. Gebhart, J. Alexiou [et al.] // Acta Chir. Belg. - 1998. - Vol. 98, № 3. - P. 120-122.

4. Intramuscular myxoma of the cervical paraspinal muscle / A. Falavigna, O. Righesso, D. Volquind, A. R. Teles // Eur. Spine J. 2009. - Vol. 18, (Suppl. 2). - P. 245-249.

5. Intramuscular myxoma of intercostal muscle; report of a case / T. Yoshioka, M. Muro, K. Kumano [et al.] // Kyobu Geka. 2010. - Vol. 63, № 6. - P. 512-515.

6. Intramuscular myxoma. A case of myxoma of the spinal erector muscle / D. Liguoro, D. Viejo-Fuertes, A. Vital [et al.] // Neurochirurgie. - 1999. - Vol. 45, № 1. - P. 54-57.

7. Intramuscular myxoma causing lumbar radiculopathy. Case report and review of the literature / K. H. Guppy, F. Wagner, R. Tawk, L. Gallagher// J. Neurosurg. -2001. - Vol. 95, (Suppl. 2). - P. 260-263.

8. Intramuscular myxoma of the lower leg / A. M. Luebke, C. Gocke, M. Priemel [et al.] // Pathologe. - 2013. - Vol. 34, № 4. -P. 360-363.

9. Two cases of angiomyxolipoma (vascular myxolipoma) of subcutaneous tissue /H. W. Lee, D. K. Lee, M. W. Lee [et al.] // J. Cutan Pathol. - 2005. - Vol. 32, № 5. - P. 379-382.

10. Kalhor N. Primary myxoma of the lung/N. Kalhor, E. M. Marom, C. A. Moran // Ann. Diagn. Pathol. - 2010. - Vol. 14, № 3. -P. 178-181. 11. Primary intracranial myxoma of the parietal region. Illustrated case report / R. K. Menon, A. Goel, A. Shah [et al.] // J. Neurooncol. - 2008. - Vol. 88, № 2. - P. 157-160.

12. Shenasky J. H. Myxoma of the kidney / J. H. Shenasky, J. Y. Gillenwater // Urology. - 1973. - Vol. 1, № 3. - P. 240-242.

13. Intramuscular myxoma of the buttock mimicking low-grade fibromyxoid sarcoma: diagnostic usefulness of MUC4 expression / H. Yamashita, K. Endo, C. Takeda [et al.] // Skeletal Radiol. 2013. - Vol. 42, № 10. - P. 1475-1479.

14. Magnetic resonance imaging of gluteal intramuscular myxoma / M. S. Yao, C. Y. Chen, J. Chin-Wei Chien [et al.] //Clin. Imaging. 2007. - Vol. 31, № 3. - P. 214-216.

15. Fluid-fluid level in a giant epidermal cyst of the buttock / N. Takemura, N. Fujii, C. Shibata [et al.] // J. Dermatol. -2007. - Vol. 34, № 3. - P. 193-197.

16. Sonography of musculoskeletal soft-tissue masses: techniques, нути великого травматичного операційного втручання - видалення утвору зі складним операційним доступом і ризиком травми органів малої миски (прямої кишки, простати, сечового міхура, судинно-нервових структур).

Висновки. Наведений клінічний випадок описує рідкісний варіант гігантської міксоми заочеревинного простору малої миски і лівої сідниці. Особливість останньої полягає у тривалості захворювання, анатомічній локалізації та розмірах утвору. Для лікування було застосовано нетипову хірургічну тактику, скеровану на забезпечення задовільної якості життя пацієнта.

pearls, and pitfalls / B. J. Carra, L. T. Bui-Mansfield, S. D. O'Brien, D. C. Chen // Am. J. Roentgenol. - 2014. - Vol. 202, № 6. - P. 1281-1290.

17. Nielsen G. P. Intramuscular myxoma: a clinicopathologic study of 51 cases with emphasis on hypercellular and hypervascular variants / G. P. Nielsen, J. X. O'Connell, A. E. Rosenberg // Am. J. Surg. Pathol. - 1998. - Vol. 22, № 10. - P. 1222-1227.

18. Intramuscular myxoma of the buttock mimicking low-grade fibromyxoid sarcoma: diagnostic usefulness of MUC4 expression/ H. Yamashita, K. Endo, C. Takeda [et al.] // Skeletal Radiol. 2013. - Vol. 42, № 10. - P. 1475-1479.

19. Mergold D. P. Myxoma of the gluteal region / D. P. Mergold // Vestn. Khir. im I. Grek. - 1955. - Vol. 76, № 9. - P. 111-112.

20. Nishio J. FDG PET/CT and MR imaging of intramuscular myxoma in the gluteus maximus / J. Nishio, M. Naito // World J. Surg. Oncol. - 2012. - Vol. 30, № 10. - P. 132.

21. Rapid Growing Intramuscular Myxoma Mimicking a Peripheral Nerve Sheath Tumor/H. Maslehaty, H. Barth, M. Mahvash [et al.] // Journal of Neurology Research. - 2011. - Vol. 1, № 2. - P. 67-69. 22. Buttock Mass in a 46-year-old Woman / J. J. King, J. R. Friedman, O. H. Iwenofu, C. M. Ogilvie// Clin. Orthop. Relat. Res. 2008. - Vol. 466, № 8. - P. 2023-2028.

23. Giant multilocular epidermoid cyst on the left buttock/ A. Polychronidis, S. Perente, S. Botaitis [et al.] // Dermatol. Surg. - 2005. - Vol. 31, № 10. - P. 1323-1324.

24. Sonographic and magnetic resonance imaging of a massive epidermoid cyst of the pelvis and buttock / O. Abulafia, G. Salame, H. L. Zinn [et al.]// J. Ultrasound Med. - 2009. - Vol. 28, № 10. - P. 1401-1403

25. Acase of giant perineal epidermal cyst: a case report/T. Machida, Y. Matsuoka, S. Kobayashi [et al.] // Hinyokika Kiyo. - 2003. Vol. 49, № 5. - P. 257-259.

26. Large epidermal cyst involving the ischiorectal fossa: MR demonstration / H. Fujimoto, K. Murakami, A. Kashimada [et al.] // Clin. Imaging. - 1993. - Vol. 17, № 2. - P. 146-148.

27. En-bloc resection of a giant retroperitoneal lipoma: a case report and review of the literature / M. Weniger, J. G. D'Haese, W. Kunz [etal.] //BMC Res/Notes. - 2015. - Vol. 8, № 1. -P. 1038. 28. Clinical utility of percutaneous biopsies of musculoskeletal tumors / C. M. Ogilvie, J. T. Torbert, J. L. Finstein [et al.] // Clin. Orthop. Relat. Res. - 2006. - Vol. 450. - P. 95-100.

29. Charron P. Intramuscular myxomas: a clinicopathologic study with emphasis on surgical management / P. Charron, J. Smith // Am. Surg. - 2004. - Vol. 70. -P. 1073-1077. 